\title{
Jewish Identities in Antiquity
}

\author{
Studies in Memory of Menahem Stern \\ Ed. by Lee I. Levine and Daniel R. Schwartz
}

[Jüdische Identitäten in der Antike. Studien zum Gedenken an Menahem Stern.]

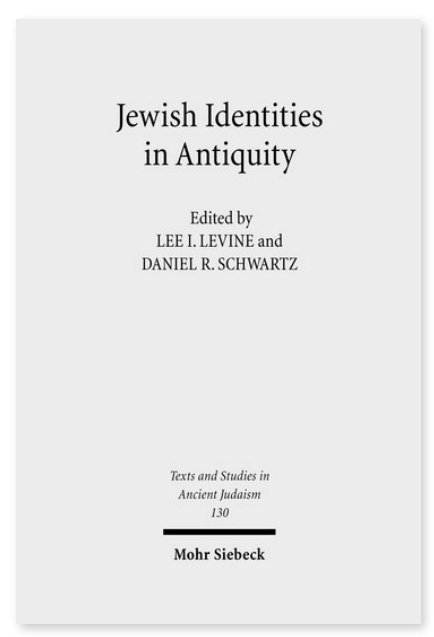

2009. XXV, 442 Seiten. TSAJ 130

ISBN 978-3-16-151463-0 DOI 10.1628/978-3-16-151463-0 eBook PDF $139,00 €$

ISBN 978-3-16-150030-5 Leinen $139,00 €$
Veröffentlicht auf Englisch.

Die Autoren der vorliegenden Studien würdigen Menahem Stern, einen der größten Gelehrten der antiken jüdischen Geschichte des 20. Jahrhunderts. Ihr Thema ergibt sich aus der Erkenntnis, dass das jüdische Leben und die jüdische Gesellschaft während der tausendjährigen Zeitspanne von Alexanders Eroberung im vierten Jh. v. Chr. bis zur arabischen Eroberung im siebten Jh. n. Chr. unzählige plötzliche wie auch schrittweise Veränderungen erfahren haben. Das hatte zur Folge, dass sich in der Antike zahlreiche Facetten jüdischen Lebens sowie viele Aspekte jüdischer Identität drastisch gewandelt haben. Die Aufsätze dieses Bandes umfassen politische, soziale, kulturelle und religiöse Sachverhalte in literarischen und archäologischen Quellen.

\section{Inhaltsübersicht}

Danie/ R. Schwartz: Menahem Stern (1924-1989): His Place in Historical Scholarship - Lee I. Levine: Jewish Identities in Antiquity: An Introductory Essay - Doron Mendels: Memory and Memories: The Attitude of 1-2 Maccabees toward Hellenization and Hellenism - Oren Tal: Hellenism in Transition from Empire to Kingdom: Changes in the Material Culture of Hellenistic Palestine - David Goodblatt: "The Israelites who reside in Judah « (Judith 4:1): On the Conflicted Identities of the Hasmonean State - Uriel Rappaport: The Connection between Hasmonean Judaea and the Diaspora - Erich S. Gruen: Kinship Relations and Jewish Identity - Sy/vie Honigman: Jewish Communities of Hellenistic Egypt: Different Responses to Different Environments - Joseph Geiger: The Jew and the Other: Doubtful and Multiple Identities in the Roman Empire - Albert I. Baumgarten: How Experiments End - Isaiah M. Gafni: Symposium: In the Wake of the Destruction: Was Rabbinic Judaism Normative? - Hillel I. Newman: The Normativity of Rabbinic Judaism: Obstacles on the Path to a New Consensus - Ze'ev Safrai and Chana Safrai: To What Extent Did the Rabbis Determine Public Norms? The Internal Evidence - David Levine: Between Leadership and Marginality: Models for Evaluating the Role of the Rabbis in the Early Centuries CE - Moshe David Herr: The Identity of the Jewish People before and after the Destruction of the Second Temple: Continuity or Change? - Steven D. Fraade: The Temple as a Marker of Jewish Identity Before and After 70 CE: The Role of the Holy Vessels in Rabbinic Memory and Imagination - Lee I. Levine: Forum: Was There a Crisis in Jewish Settlement in the Eastern Galilee of Late Antiquity? - Uzi Leibner: Settlement Patterns in the Eastern Galilee: Implications Regarding the Transformation of Rabbinic Culture in Late Antiquity - Jodi Magness: Did Galilee Experience a Settlement Crisis in the Mid-Fourth Century? - Uzi Leibner: The Settlement Crisis in the Eastern Galilee during the Late Roman and Early Byzantine Periods: Response to Jodi Magness - Tessa Rajak: The Greek Bible Translations among Jews in the Second Century CE - Isaiah M. Gafni: How Babylonia Became »Zion«: Shifting Identities in Late Antiquity - Adie/ Schremer: The Christianization of the Roman Empire and Rabbinic Literature - Zeev Weiss: Between Rome and Byzantium: Pagan Motifs in Synagogue Art and Their Place in the Judaeo-Christian Controversy - Oded Irshai: Jewish Violence in the Fourth Century CE - Fantasy and Reality: Behind the Scenes under the Emperors Gallus and Julian

Lee I. Levine is Professor emeritus of Jewish History and Archaeology at the Hebrew University of Jerusalem.

Daniel R. Schwartz Born 1952; 1971 immigrated to Israel; 1979 PhD; since 1979 teaching at Dept. of Jewish History, Hebrew University, Jerusalem; since 1995 full professor; since 2011 academic head of Mandel Scholion - Interdisciplinary Research Center in the Humanities and Jewish Studies.

Jetzt bestellen:

https://mohrsiebeck.com/buch/jewish-identities-in-antiquity-9783161514630?no_cache=1 order@mohrsiebeck.com

Telefon: +49 (0)7071-923-17

Telefax: $+49(0) 7071-51104$ 